\title{
Financial Performance Determinants of Organi- zations: The Case of Mongolian Companies
}

\section{- Bayaraa Batchimeg}

\begin{abstract}
This paper is aimed at examining what ratios can determine financial performance of Mongolian companies which are divided into 6 major sectors to increase their competitiveness. This study analyzes the performance of companies in terms of profitability and its association with multiple determinants for 100 Mongolian joint stock companies (JSC) listed in Mongolian Stock Exchange (MSE). Financial statements of those companies from MSE are evaluated by panel regression covering the period of 2012-2015. Return on Assets (ROA), Return on Equity (ROE), and Return on Sales (ROS) are chosen as performance indicators, while growth in sales, growth in profit, growth in assets, earnings per share, gross profit margin, cost to revenue ratio, return on costs, short-term debt to assets ratio, current assets to total assets ratio, long-term debt to total assets, quick ratio, current ratio, and cash ratio are used as explanatory variables. The panel regression results show that ROA has more determinants than ROE and ROS, such as earnings per share, return on costs have positive impacts, while short-term debts to total assets ratio and cost to revenue ratio have negative impacts. Growth in sales, earnings per share and costs to revenue ratio influence positively the financial performance of an organization by ROS, while return on cost has a positive effect on the financial performance measured by return on sale.
\end{abstract}

Keywords: financial performance, determinants, capital structure, Mongolian joint stock companies, corporate efficiency, Return on Assets, Return on Equity, Return on Sales, Mongolian Stock. Exchange

JEL Classification: C14, C300, L250

\section{INTRODUCTION}

Coexisting globalization, competitiveness among the companies are becoming severe. Competitiveness is determined by the effectiveness and efficiency (Csath, 2007). However, it is important to examine the financial performance determinants of a company, it is impossible that every sector has the same determinants, since they differ by their operations and characters. The competitiveness of a corporation and its performance is judged by comparison with its peers and against the best practice (Manzoni, 2007). Therefore, the main purpose of the research is examining financial determinants for Mongolian sectors, comparing and explaining the results. This research is restricted to the relationship among Return on Assets (ROA), Return on Equity (ROE) and Return on Sales (ROS) with its internal factors as determinants over the period of 2012-2015 in Mongolian JSCs. Even though there are many external factors, such as income per capita, inflation and unemployment rate, external factors are beyond the scope of this study. Based on the data availability, 100 companies' financial statements are used in the research; however, currently 227 companies are listed on MSE. In other words, a company selection is based on having all data for the time period used. 
In order to present investors with a concise view of Mongolian economy, Mongolian businesses are hereby classified into 20 business sectors. For this study, companies are divided into 6 sectors, i.e., food and grocery, production of construction, mining, agriculture, trading, service, and miscellaneous.

The objectives of the study are the answers to the questions below:

1. To examine the internal factors on financial performance of each 6 sectors in Mongolia.

2. To find out if the relationships between financial performance and variables are negative or positive.

3. To offer suggestions of how to improve financial performance of particular sectors.

The rest of this paper is organized as follows: Section two reviews the literature about financial performance, growth, liquidity and profitability. Section three provides the data and variables, and the methodology of this study. Section four consists of empirical results and discussion. Finally, conclusions are drawn in section five.

\section{LITERATURE REVIEW}

Company performance is the measurement of what had been achieved by a company which shows good conditions for certain period of time. The purpose of measuring the achievement is to obtain useful information related to flow of fund, the use of fund, effectiveness, and efficiency. Besides, the information can also motivate the managers to make the best decision (Amal, Sameer, \& Yahya, 2012).

\subsection{Growth}

Elliot (1972) measured 88 companies in six categories, including liquidity, growth, owner earnings, management profit performance, leverage, and capital investment. He concluded that the growth variables did not have any significant influence on financial performance.

\subsection{Profitability}

More than any other accounting measure, profits demonstrate how well management is doing in investment and financing decisions. Profitability ratios measure how effectively a firm's management is generating profits on sales, total assets, and, most importantly, stockholders' investment. Therefore, anyone whose economic interests are tied to the long-run survival of a firm will be interested in profitability ratios (Moyer, James , \& William , 2006). For this study, ROA, ROE and ROS are used as dependent variables, while gross profit margin, cost to revenue ratio and return on costs are chosen as explanatory variables to reveal the connection between financial performance and profitability.

\subsection{Capital structure}

Capital structure is also an important factor that determines the performance of a firm. Capital structure refers to the ratio of debt and equity financing (Sidra \& Attiya, 2013). There should be an appropriate capital structure that generates the maximum profit for the organization, as too 
less equity financing increases the control of the owners to a large extent (Abu-Rub, 2012).

Dasuki (2016) examined the effect of capital structure on financial performance of 180 manufacturing companies listed on Borsa Stock Exchange Istanbul Turkey over the period of 2004 to 2013. He studied two dependent variables ROA and ROE, and concluded that the long-term debt and total debt have significant negative effects on the financial performance measures by ROA, while those ratios were statistically insignificant on the financial performance measured by ROE (Dasuki, 2016).

Onaolapo and Kajola (2010) examined the impact of capital structure on firm's financial performance using a sample of thirty non-financial firms listed on the Nigerian Stock Exchange during the seven- year period, 2001- 2007. They found a result which showed a firm's capital structure surrogated by Debt Ratio. It had a significant negative impact on the firm's financial measures which were Return on Asset and Return on Equity (Onaolapo \& Kajola, 2010).

Sidra and Attiya (2013) examined determinants of financial performance by using corporate governance, ownership structure, capital structure, economic indicators and risk management as independent variables. They studied 60 Pakistani corporate firms listed in Karachi stock exchange for the period of 2007 to 2011 by fixed effects panel regression. The conclusion drawn from their study is that the debt to equity ratio has a positive impact on performance, while the long-term debt to total assets and short-term debt to total assets have a negative impact on firm performance.

\subsection{Liquidity}

The effective liquidity management - beyond securing their survival - helps companies to reach higher profitability by reducing their input needs. Furthermore, it grants strategic advantages in the economically difficult time periods (Veronika, Tarnóczi , \& Vörös ,2014).

Both long-term and short-term creditors are concerned with the amount of leverage a company employs because it indicates the company's risk exposure in meeting debt service charges i.e. interest and principal repayment. A company that is heavily financed by debt gives creditors less protection in the event of bankruptcy (Moyer, James, \& William, 2006).

Liquidity ratios show the relationship of a firm's current assets to its current liabilities, and thus its ability to meet maturing debts. Two commonly used ratios are the current ratio and the quick ratio (Brigham \& Micheal, 2008), which are used as variables together with cash ratio in this research.

Amal et.al., (2012) examined the factors that mostly affect financial performance of Jordanian Insurance Companies, based on the data from Amman Stock Exchange during the period of 2002-2007 with the observation of 25 insurance companies. Their results showed that the following variables: leverage, liquidity, size and management competence index have positive statistical effects on the financial performance of Jordanian Insurance Companies (Amal, Sameer, \& Yahya, 2012).

Ana and Ghiorghe (2014) attempted to analyze determinants of the financial performance in the Romanian insurance market during the period of 2008-2012 using 21 insurance companies' 
financial statements from the Insurance Supervisory Commission. They achieved the results that determinants were the financial leverage, company size, growth of gross written premiums, underwriting risk, risk retention ratio and solvency margin (Burca \& Ghiorghe, 2014).

\section{DATA, VARIABLES AND RESEARCH METHODOLOGY}

\subsection{Data}

Financial statements used as data are obtained from MSE's website. Stock Exchanged was established in connection with the transition period from a centrally planned economy to a market economy in Mongolia on 18 January 1991. Mongol Shiltgeen company became a public company by issuing 10 million shares and 1 million shares of them offered to public and registered at Mongolian Stock Exchange on 25 May, which was the first IPO launched in Mongolia (www.mse.mn, 2017). According to the Mongolian law of auditing, JSCs' financial statement must be audited before stockholders' meeting which increases reliability of the data compared with non-public companies' financial statements (legalinfo.mn, 2015). This study used the panel regression of 100 Mongolian JSCs' financial statements for 4 years (400 observations).

\subsection{Firm's Performance Variables}

In this study, ROA, ROE and ROS are used as dependent variables representing financial performance, while ratios what express growth, capital structure, liquidity, and profitability are chosen as independent score variables.

Explained variables

- Return on Equity (ROE): dividing the net income by stockholders' equity.

- Return on Sales (ROS): dividing the amount of sales.

- Return on Assets (ROA): dividing the net income by total assets.

Explanatory variables

- Growth in sales: dividing current year's sales by preceding year's sales.

- Growth in assets: dividing current year's assets by preceding year's assets.

- Growth in profit: dividing current year's after tax profit by preceding year's after tax profit.

- Gross profit margin: subtracting costs of goods sold from revenue and dividing the figure by revenue.

- Earnings per share: dividing after tax profit by the number of shares. (None of the companies in the data has preferred stock.)

- Cost to revenue ratio: dividing total costs by total revenue.

- Long-term debt to total assets: long-term debt divided by total assets.

- Short-term debt to total assets: short-term debt divided by total assets.

- Current assets to total assets ratio: current assets divided by total assets. 
- Quick ratio: subtracting inventory from current assets and dividing the figure by short-term debts.

- Cash ratio: the ratio is calculated as the amount of cash divided by short-term debts.

- Current ratio: the ratio is calculated as current assets divided by total short-term debts.

Tab. 1 - Variables. Source: author's own calculation

\begin{tabular}{|c|c|c|c|}
\hline \multicolumn{2}{|c|}{ Dependent variable } & \multicolumn{2}{|c|}{ Independent variable } \\
\hline ROA & Return on assets & \multirow{3}{*}{ Growth } & Growth in sales \\
\hline ROE & Return on equity & & Growth in assets \\
\hline ROS & Return on sales & & Growth in profit \\
\hline & & \multirow{3}{*}{ Profitability } & Gross profit margin \\
\hline & & & Earnings per share \\
\hline & & & Cost to revenue ratio \\
\hline & & \multirow{3}{*}{ Capital structure } & Current assets to total assets ratio \\
\hline & & & Long-term debts to total assets ratio \\
\hline & & & Short-term debts to total assets ratio \\
\hline & & \multirow{3}{*}{ Liquidity } & Quick ratio \\
\hline & & & Cash ratio \\
\hline & & & Current ratio \\
\hline
\end{tabular}

\subsection{Research Methodology}

The empirical analysis will be done panel regression on R statistical system. Since the data chosen for this study contains companies with corresponding years, we used the panel data analysis (HSIOA, 2003). The fixed effects model is an appropriate specification if we are focusing on a specific set of $\mathrm{N}$ firms and our inference is restricted to behavior of these sets of firms, while the random effects model is an appropriate specification if we are drawing $\mathrm{N}$ individuals randomly from a large population (Baltagi, 2005). Fixed effects or random effects model, whichever is appropriate, will be used to find the results based on the Hausman specification test in that study. Three ratios are used as dependent variables (ROE, ROA and ROS) separately, and their results are examined to determine the financial performance impacts for each of 6 sectors.

\section{ANALYSIS AND RESULTS}

Tab. 2 - Descriptive statistics. Source: author's own calculation

\begin{tabular}{|l|c|c|c|c|c|}
\hline \multirow{2}{*}{ Sectors } & \multirow{2}{*}{$\begin{array}{c}\text { Observa- } \\
\text { tions }\end{array}$} & \multicolumn{2}{|c|}{ ROA } & \multicolumn{2}{|c|}{ ROE } \\
\cline { 3 - 6 } & Mean & Std. deviation & Mean & Std. deviation \\
\hline $\begin{array}{l}\text { Food and grocery } \\
\text { sector }\end{array}$ & 44 & 0.0488 & 0.1244 & 0.0641 & 0.2769 \\
\hline
\end{tabular}




\begin{tabular}{|l|c|c|c|c|c|}
\hline $\begin{array}{l}\text { Construction } \\
\text { sector }\end{array}$ & 48 & 0.0001 & 0.0959 & -0.0077 & 0.1967 \\
\hline Mining sector & 40 & -0.0400 & 0.3407 & 0.1008 & 0.4943 \\
\hline Service sector & 144 & 0.0006 & 0.1440 & -0.1747 & 1.8138 \\
\hline $\begin{array}{l}\text { Agricultural } \\
\text { sector }\end{array}$ & 56 & -0.0044 & 0.1094 & -0.1549 & 1.4043 \\
\hline Miscellaneous & 68 & -0.0342 & 0.1574 & 0.2417 & 0.9053 \\
\hline Total & 400 & -0.0048 & 0.1671 & -0.0273 & 1.2846 \\
\hline
\end{tabular}

The descriptive statistics (Table 2) shows that the mean of ROA is the highest in the food and grocery sector, while ROE is the highest in the sector miscellaneous. On the other hand, the mean of ROA is the lowest in the sector miscellaneous, and ROE is the lowest in the service sector. However, the standard deviation of the service sector is 1.8138 , which is the highest deviation. It shows the companies in the service sector vary greatly by their ROE.

Tab. 3 - General: significant variables predicting ROA (Random effect model). Source: author's own calculation

\begin{tabular}{|l|c|l|}
\hline Name & Coefficient & Sig \\
\hline Growth in profit & -0.0001 & $* *$ \\
\hline Earnings per share & 0.0003 & $* * *$ \\
\hline Cost to revenue ratio & -0.0003 & $* * *$ \\
\hline Short-term debt to asset ratio & -0.2361 & $* * *$ \\
\hline Current assets to total assets & 0.007 & $* * *$ \\
\hline Long-term debt to total asset & -0.303 & $* * *$ \\
\hline Current ratio & -0.0002 & $*$ \\
\hline Factor (year) 2015 & -0.0041 & $* *$ \\
\hline Factor (Type of business) Mining sector & -0.006 &. \\
\hline Factor (Type of business) Food and grocery sector & -0.005 &. \\
\hline Factor (Type of business) Service sector & -0.009 & $* * *$ \\
\hline Factor (Type of business) Construction service & -0.008 & $* *$ \\
\hline R-squared: & 0.561 & \\
\hline Adjusted R-squared: & 0.530 & \\
\hline
\end{tabular}

Significance codes: 0 (***) 0.001 (**) 0.01 '*’ 0.05 ‘ 0.1 “ “ 1

In Table 3, we can see that earnings per share and current assets to total assets ratio have significant positive impacts on ROA, while other ratios have negative impacts. As seen above, there is some difference in ROAs among the sectors, particularly for service and construction sectors. But the ROA difference for agriculture and miscellaneous sectors were insignificant. Since we saw ROA's difference among the sectors, performance measurements are calculated for each sector below. 
Tab. 4 - Food and grocery sector: significant variables predicting ROA and ROE. Source: author's own calculation

\begin{tabular}{|c|c|c|c|c|c|}
\hline \multicolumn{3}{|l|}{ Return on assets } & \multicolumn{3}{|l|}{ Return on equity } \\
\hline Name & Coefficient & Sig & Name & Coefficient & Sig \\
\hline Earnings per share & 0.0003 & . & Earnings per share & 0.0007 & $*$ \\
\hline Gross profit margin & 0.158 & $* * *$ & Gross profit margin & 0.202 & $*$ \\
\hline Cash ratio & 0.0004 & $* *$ & Return on costs & 0.511 & $* *$ \\
\hline \multirow[t]{2}{*}{$\begin{array}{l}\text { Current assets to asset } \\
\text { ratio }\end{array}$} & 0.327 & ** & $\begin{array}{l}\text { Current assets to asset } \\
\text { ratio }\end{array}$ & 0.643 & ** \\
\hline & & & Cash ratio & 0.0007 & $*$ \\
\hline \multicolumn{2}{|l|}{ R-squared: } & 0.816 & \multicolumn{2}{|l|}{ R-squared: } & 0.853 \\
\hline \multicolumn{2}{|l|}{ Adjusted R-squared: } & 0.556 & \multicolumn{2}{|l|}{ Adjusted R-squared: } & 0.582 \\
\hline \multicolumn{2}{|l|}{ Hausman test $\mathrm{p}$-value } & 0.247 & \multicolumn{2}{|l|}{ Hausman test $\mathrm{p}$-value } & 0.053 \\
\hline
\end{tabular}

Significance codes: 0 (***’ 0.001 '**’ 0.01 '*’ 0.05 ‘? 0.1 “ ‘ 1

Based on the Hausman test's result, we used the random effects model for the food and grocery sector. As seen in the Table 4, earnings per share, gross profit margin, cash ratio, current assets have significant positive impacts on ROA and ROE. As for the food and grocery sector, it is required to produce a huge amount of products which makes the amount of current assets relatively higher than that of the other sectors. We can conclude that solvency influences positively the food and grocery sector's profitability. Those variables cannot explain the ROS significantly for the food and grocery sector, except the long-term debt to total assets ratio has a negative effect of $10 \%$ significance level.

Tab. 5 - Construction sector: significant variables predicting ROA and ROE. Source: author's own calculation

\begin{tabular}{|l|l|l|l|l|l|}
\hline Return on assets & Coefficient & Sig & Name & Coefficient & Sig \\
\hline Name & 0.0003 & $* *$ & Cost to revenue ratio & -0.001 &. \\
\hline Earnings per share & 0.100 & $* * *$ & Return on cost & 0.222 & $*$ \\
\hline Return on cost & & & Growth in assets & -0.056 &. \\
\hline & 0.718 & R-squared: & & 0.726 \\
\hline R-squared: & 0.509 & Adjusted R-squared: & 0.348 \\
\hline Adjusted R-squared: & 0.211 & Hausman test p-value & 0.8303 \\
\hline Hausman test p-value & & $0.0 \%$ & \\
\hline
\end{tabular}

Significance codes: 0 (***) 0.001 '**’ 0.01 '*’ 0.05 ‘ 0.1 “ “ 1

Based on the Hausman test's result, we used the random effects model for the construction sector. Table 5 shows the return on cost ratio has a positive effect for both ROA and ROE, while cost to revenue ratio and growth in assets have negative impacts on ROE. We can assume that return on cost is a determinant of the construction sectors' financial performance, as the con- 
struction sector differs by its durable or long lasting outputs which require a lot of expenses and many workers so that return on cost is the most crucial determinant. Those variables cannot explain the ROS significantly for the construction sector, except return on costs ratio has a positive effect at $5 \%$ significance level.

Tab. 6 - Mining sector: significant variables predicting ROA and ROS. Source: author's own calculation

\begin{tabular}{|l|l|l|l|l|l|}
\hline Return on assets & Coeff & Sig & Name & Coeff & Sig \\
\hline Name & -0.001 &. & Growth in sales & 0.022 & $*$ \\
\hline Cost to revenue ratio & -0.524 & $* * *$ & Earnings per share & 0.022 & $*$ \\
\hline Long-term debt to assets & & & Cost to revenue ratio & 0.040 & $* * *$ \\
\hline & & & Return on cost & 5.623 & $* * *$ \\
\hline & & 0.865 & R-squared: & & 0.761 \\
\hline R-squared: & & 0.562 & Adjusted R-squared: & & 0.514 \\
\hline Adjusted R-squared: & & 1.000 & Hausman test p-value & & 1.000 \\
\hline Hausman test p-value & & & & & \\
\hline
\end{tabular}

Significance codes: 0 (***) $0.001^{\text {( } * *)} 0.01$ '*’ 0.05 ‘ 0.1 “' 1

The random effects model was used according to the Hausman test's result for the mining sector. In Table 6, long-term debt to assets ratio is a fundamental determinant for ROA which has a significant negative effect, while return on cost determines ROS in the mining sector. The mining sector and the construction sectors are similar by their longer life cycle compared with the other sectors. As for the mining industry, there is a period of time the whole costs have to be paid by equity or debt since the first revenue is mostly expected after years. That is why mining companies have a huge amount of debt with a high-interest rate, and that high-interest rate reduces the profitability. A negative relationship of long-term debt to total assets ratio and ROA is consistent with Dasuki (2016) and Sidra\&Attiya (2013). Those variables cannot explain the ROE significantly for the mining sector.

Tab. 7 - Agricultural sector: significant variables predicting ROA and ROS. Source: author's own calculation

\begin{tabular}{|l|l|l|l|l|l|}
\hline \multicolumn{2}{|l|}{ Return on assets } & \multicolumn{4}{l|}{ Return on sales } \\
\hline Random effect model & Coefficient & Sig & Name & Coefficient & Sig \\
\hline Name & 0.006 & $* * *$ & Gross profit margin & -3.656 & $*$ \\
\hline Earnings per share & $*$ & $\begin{array}{l}\text { Current assets to } \\
\text { total assets }\end{array}$ & -12.107 & $*$ \\
\hline Cost to revenue ratio & -0.0002 & $* * *$ & $\begin{array}{l}\text { Long-term debt to } \\
\text { assets }\end{array}$ & 22.242 & $* *$ \\
\hline Return on costs & -0.0137 & - & & & 0.516 \\
\hline Cash ratio & -0.0001 & 0.748 & R-squared: & & \\
\hline R-squared: & & & & & \\
\hline
\end{tabular}




\begin{tabular}{|l|c|l|c|}
\hline Adjusted R-squared: & 0.561 & Adjusted R-squared: & 0.267 \\
\hline Hausman test p-value & 0.999 & Hausman test p-value & 0.009 \\
\hline
\end{tabular}

Significance codes: 0 ‘***’ 0.001 ‘**’ 0.01 ‘*’ 0.05 ‘’ 0.1 “ ‘ 1

Based on the Hausman test's result, we used the random effects model for ROA, the fixed effects model for ROS in the agricultural sector. From Table 7, we can conclude that the long-term debt to assets ratio, which has a significant positive impact, can be the determinant for ROS. However, this positive impact contradicts the result of the mining sector which is negative. Earnings per share and return on costs determine ROA for the agricultural sector. It is noteworthy that the solvency determines performance in the agricultural sector greatly. The variables cannot explain the ROE significantly for the agricultural sector.

Tab. 8 - Service sector: significant variables predicting ROA, ROE and ROS. Source: author's own calculation

\begin{tabular}{|c|c|c|c|c|c|c|c|c|}
\hline \multicolumn{3}{|c|}{ Return on assets } & \multicolumn{3}{|c|}{ Return on equity } & \multicolumn{3}{|c|}{ Return on sales } \\
\hline Name & Coeff & Sig & Name & Coeff & Sig & Name & Coeff & Sig \\
\hline $\begin{array}{l}\text { Return on } \\
\text { costs }\end{array}$ & 0.231 & $* * *$ & $\begin{array}{l}\text { Return on } \\
\text { costs }\end{array}$ & 2.883 & $* *$ & $\begin{array}{l}\text { Return } \\
\text { on costs }\end{array}$ & 16.07 & $* * *$ \\
\hline \multirow[t]{3}{*}{$\begin{array}{l}\text { Short-term } \\
\text { debt to total } \\
\text { assets }\end{array}$} & -0.60 & $* * *$ & $\begin{array}{l}\text { Short-term } \\
\text { debt to } \\
\text { total assets }\end{array}$ & -3.432 & $*$ & $\begin{array}{l}\text { Current } \\
\text { assets to } \\
\text { total as- } \\
\text { sets ratio }\end{array}$ & 19.81 & $* *$ \\
\hline & & & $\begin{array}{l}\text { Earnings } \\
\text { per share }\end{array}$ & -0.006 & * & $\begin{array}{l}\text { Current } \\
\text { ratio }\end{array}$ & -0.03 & $* *$ \\
\hline & & & $\begin{array}{l}\text { Growth in } \\
\text { sales }\end{array}$ & -0.008 & $* *$ & & & \\
\hline \multicolumn{2}{|l|}{ R-squared: } & 0.728 & \multicolumn{2}{|l|}{ R-squared: } & 0.432 & \multicolumn{2}{|c|}{ R-squared: } & 0.389 \\
\hline \multicolumn{2}{|c|}{ Adjusted R-squared: } & 0.476 & \multicolumn{2}{|c|}{ Adjusted R-squared: } & 0.283 & \multicolumn{2}{|c|}{$\begin{array}{l}\text { Adjusted R- } \\
\text { squared: }\end{array}$} & 0.257 \\
\hline \multicolumn{2}{|c|}{ Hausman test $\mathrm{p}$-value } & 0.001 & \multicolumn{2}{|c|}{$\begin{array}{l}\text { Hausman test } \mathrm{p}^{-} \\
\text {value }\end{array}$} & $9.867 \mathrm{e}-10$ & \multicolumn{2}{|c|}{$\begin{array}{l}\text { Hausman test } \\
\text { p-value }\end{array}$} & $2.2^{\mathrm{e}-16}$ \\
\hline
\end{tabular}

Significance codes: 0 ‘***’ $0.001^{\text {‘**’ }} 0.01^{\text {'*’ }} 0.05$ '? 0.1 ' ‘ 1

The fixed effects model was used according to the Hausman test's result for the service sector. From Table 8, we can see that return on costs have a significant positive impact on all dependent variables. Moreover, the short-term debt to total assets ratio affects negatively both ROA and ROE, which is consistent with Sidra\&Attiya (2013). Current assets to total assets ratio is an important factor for the service sector's ROS. Based on the calculation, we can conclude that return on cost and short-term solvency determines the financial performance in the service sector, while long-term solvency and asset's structure were insignificant. 
Tab. 9 - Miscellaneous: significant variables predicting ROA and ROS. Source: author's own calculation

\begin{tabular}{|c|c|c|c|c|c|}
\hline \multicolumn{3}{|l|}{ Return on assets } & \multicolumn{3}{|l|}{ Return on sales } \\
\hline \multicolumn{3}{|l|}{ Fixed effect model } & \multicolumn{3}{|l|}{ Random effect model } \\
\hline Name & Coefficient & Sig & Name & Coefficient & Sig \\
\hline Gross profit margin & 0.096 & . & Growth in sales & 0.004 & $*$ \\
\hline $\begin{array}{l}\text { Short-term debt to } \\
\text { total assets }\end{array}$ & -0.202 & $*$ & Growth in assets & -0.159 & $*$ \\
\hline \multirow[t]{2}{*}{ Cash ratio } & 0.0003 & . & Earnings per share & 0.007 & $* * *$ \\
\hline & & & Cost to revenue ratio & 0.003 & . \\
\hline \multicolumn{2}{|l|}{ R-squared: } & 0.516 & \multicolumn{2}{|l|}{ R-squared: } & 0.415 \\
\hline \multicolumn{2}{|l|}{ Adjusted R-squared: } & 0.288 & \multicolumn{2}{|l|}{ Adjusted R-squared: } & 0.335 \\
\hline \multicolumn{2}{|l|}{ Hausman test $\mathrm{p}$-value } & $1.27 \mathrm{e}-08$ & \multicolumn{2}{|l|}{ Hausman test $\mathrm{p}$-value } & 0.228 \\
\hline
\end{tabular}

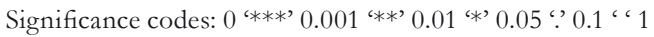

Based on the Hausman test's result, we used the random effects model for ROS, fixed effects model for ROA in the sector miscellaneous. In Table 9, the short-term debt to total assets ratio has negative impacts on ROA, while growth in assets has a negative one, and earnings per share have positive impacts on ROS. It is seen that variables do not explain the sector's financial determinants as they do for other sectors. The reason behind this is that the sector miscellaneous has unrelated companies, which makes it difficult to compare and analyze.

\section{CONCLUSION}

The aim of this study is to investigate the impacts of profitability, growth, liquidity and capital structure on the financial performance of 6 major sectors in Mongolia, and evaluate if there is any difference related with its sector. The paper uses the panel regression to examine the financial performance determinants for Mongolia's 6 sectors. The Hausman test is used to decide, using either fixed effects or random effects model. ROA, ROE and ROS are chosen as dependent variables. Out of 13 independent variables, growth in profit, quick ratio, current ratio and growth in assets were insignificant factors for each of 6 sectors. It shows that liquidity and growth cannot express financial performance. Generally, return on costs was one of the most crucial determinants which have a positive significant impact on the food \& grocery, construction, mining, and service sectors. After that, the earnings per share is the important variable, which is seen as a determinant for the food \& grocery, construction, mining, and agricultural sectors. From these results, we conclude that capital structure, cost structure and profitability are the determinants of financial performance in Mongolia. Moreover, there are some determinants connected with certain sector, such as long-term debt to total assets ratio is significant for the mining and agricultural sector only, while short-term debt to total assets ratio is the determinant for the service sector only. Short-term solvency is fundamental for the food and grocery, agriculture, and service sector connected with their life cycle, while the mining sector is determined by its long-term solvency. 


\section{Limitations and Recommendations}

There is a need for further analyses with respect to the external factors of financial performance. This research uses only four years' financial statements, which is a relatively short-time period, and uses only joint stock companies' statements. Therefore, a further researcher may extend the present study by more years and by non-public companies' statements.

\section{References}

1. Almajali, A. Y., Alamro, S. A., \& Al-Soub, Y. Z. (2012). Factors Affecting the Financial Performance of Jordanian Insurance Companies Listed at Amman Stock Exchange. Journal of Management Research, 4(2), 266-289. https://doi.org/10.5296/jmr.v4i2.1482.

2. Baltagi, B. H. (2005). Econometric analysis of panel data. Vasa, 66-73. I .

3. Brigham, E. F., \& Micheal, C. E. (2008). Financial Management: Theory and Practice 12th edition, 133-150.

4. Burca, M. \& Batrinca, G. (2014). The determinants of financial performance in the Romanian insurance market. International Journal of Academic Research in Accounting, Finance and Management Sciences, 4 (1), 299-308. http://dx.doi.org/10.6007/IJARAFMS/v4-i1/637.

5. Capon, N., Farley, J. U., \& Hoenig, S. (1990). Determinants of financial performance: a meta-analysis. Management Science, 36(10), 1143-1159. http://dx.doi.org/10.1287/ mnsc.36.10.1143.

6. Csath, M. (2007). The competitiveness of economies: different views and arguments. Society and Economy, 29(1), 87-102. http://dx.doi.org/10.1556/SocEc.29.2007.1.4.

7. Dasuki, A. I. (2016). The effect of capital structure on financial performance. DOKBAT conference proceedings, 95-104.

8. Elliott, J. (1972). Control, Size, Growth, and Financial Performance in the Firm. The Journal of Financial and Quantitative Analysis, 7(1), 1309-1320. http://dx.doi.org/10.2307/2330065.

9. Hsiao, C. (2004). Analysis of panel data. Computers \& Mathematics with Applications, 47(6-7), 1147-1148. https://doi.org/10.1016/S0898-1221(04)90099-5.

10. Kipesha, E. F., \& James, J. M. (2014). Capital Structure and Firm Performance: Evidences from Commercial Banks in Tanzania. Research Journal of Finance and Accounting, 5(14), 168-179.

11. Law of Auditing. (2015). Retrieved January 16, 2017, from http://legalinfo.mn/law/details/ 11192?lawid=11192.

12. Manzoni, A. (2007). A new approach to performance measurement using data envelopment analysis: implications for organisation behaviour, corporate governance and supply chain. Victoria University. Retrieved from http://vuir.vu.edu.au/1530/.

13. Mirza, S., \& Javed, A. (2013). Determinants of financial performance of a firm: Case of Pakistani stock market. Journal of Economics and International Finance, 5(2), 43-52. http:// dx.doi.org/10.5897/JEIF12.043.

14. Moyer, C., R.McGulgan, J., \& J.Kretlow, W. (2005). Contemporary Financial Management. Cengage Learning, 64-96. ISBN 0314913483. 
15. The History of Mongolian Stock Exchange. (2016). Retrieved January 24, 2017, from http://mse.mn/mn/content/list/6.

16. Veronika, F., Tibor, T., \& Péter, V. (2014). Financial Indicators in Managerial DecisionMaking. Annals of the University of Oradea, Economic Science Series, 23(1), 893-904.

\section{Contact information}

Ph.D. student, Batchimeg Bayaraa

University of Debrecen, Faculty of Business and Management

Egyetem tér 1, 4010 Debrecen, Debrecen, Hungary

Bayaraa.batchimeg@econ.unideb.bu 